\title{
Case report: a case of eruptive collagenoma occurring in esophagus and intestine
}

\author{
Ping Gao, Lili Jing, Hai Huang, Cuiping Zhang and Junmei Hao*
}

\begin{abstract}
Background: Eruptive collagenoma is a rare disease. All of the previously reported cases were located on the skin. Here we report such a case occurring in esophagus and intestine.

Case presentation: Our patient is a Chinese woman. Two years ago, hundreds of small nodules were identified in her esophagus and intestine. The lesions were characterized by thickened hyalinized collagen fibers and haphazard neoplastic stellate cells. The tumor cells showed generally positive for vimentin and negative for h-CALD, CD34, desmin, CD163, AE1/AE3, CK7 and CK20. The nodules were blue with Masson Trichrome stain. The clinicopathological, immunohistochemical and histochemical features of the tumor were consistent with eruptive collagenoma. The patient was not given specific treatment after diagnosis, and a routine examination indicated that there was no progress for 2 years.

Conclusion: Hitherto, this is the first case of eruptive collagenoma to have been reported occurring in esophagus and intestine.
\end{abstract}

Keywords: Eruptive collagenoma, Esophagus, Intestine

\section{Background}

Eruptive collagenoma is a rare acquired connective tissue hamartoma. The first case was described by Cramer in 1966 [1], and a few other cases displaying similar features have been reported since [2-14]. Here, we report such a case occurring in the whole esophagus and intestine. We describe the histopathological features of the lesions as well as the differential diagnoses.

\section{Case presentation}

Our patient is a 51-year-old female. Two years ago, she presented with minor abdominal discomfort and dyspepsia for one month. Endoscopy revealed that hundreds of nodules, ranging from $2 \mathrm{~mm}$ to $5 \mathrm{~mm}$ in diameter, protruded from mucosa in her whole esophagus and intestine (Fig. 1a-c). No ulcer or other abnormal manifestations could be observed. Biopsies were taken from different sites. Laboratory analysis indicated a slightly high IgG level of $25.9 \mathrm{~g} / \mathrm{L}$ (normal 8.0-17.0 g/L), IgA level of $4.46 \mathrm{~g} / \mathrm{L}$ (normal $0.72-4.29 \mathrm{~g} / \mathrm{L}$ ) and a slightly low complement C3 level of $0.73 \mathrm{~g} / \mathrm{L}$ (normal $0.79-1.52 \mathrm{~g} / \mathrm{L}$ ),

*Correspondence: ytfyblk@163.com

Department of Pathology, Yantai Affiliated Hospital of Binzhou Medical

University, No. 717, Jinbu Street, Yantai, Shandong Province 264100, China complement C4 level of $0.14 \mathrm{~g} / \mathrm{L}$ (normal $0.16-0.38 \mathrm{~g} / \mathrm{L}$ ), and normal ranges for CEA $(1.17 \mathrm{ng} / \mathrm{ml}$, normal 0.00 $5.00 \mathrm{ng} / \mathrm{ml})$ and AFP $(1.40 \mathrm{ng} / \mathrm{ml}$, normal $0.00-8.10 \mathrm{ng} /$ $\mathrm{ml})$. Qualitative check of Bence-Jones protein was negative in urine. The suspected clinical diagnosis was primary systemic amyloidosis, and whether it is a hereditary disease should be differentiated. Her parents and younger sister were all given endoscopy examinations following the patient, but no similar nodules were found in them.

Biopsy tissues from esophagus, terminal ileum, cecum, colon and rectum were submitted for pathological examination. The histopathological characteristics of each specimen were similar. The mucosa was unremarkable, epithelial cells demonstrated bland nuclei, with no atypia or mitotic activity. And no lymphoid inflammatory infiltration in the stroma was observed. In submucosa, there were several small round nodules which were well circumscribed and unencapsulated. The nodules were predominantly composed of collagen bundles, and a variable number of stellate tumor cells located within the collagen (Fig. 1d-f). The collagen were hyalinized and no skeinoid fibers could be observed. The tumor cells were haphazard and not arranged in storiform or palisading pattern. In most nodules, they located peripherally; but in a few nodules, they located 


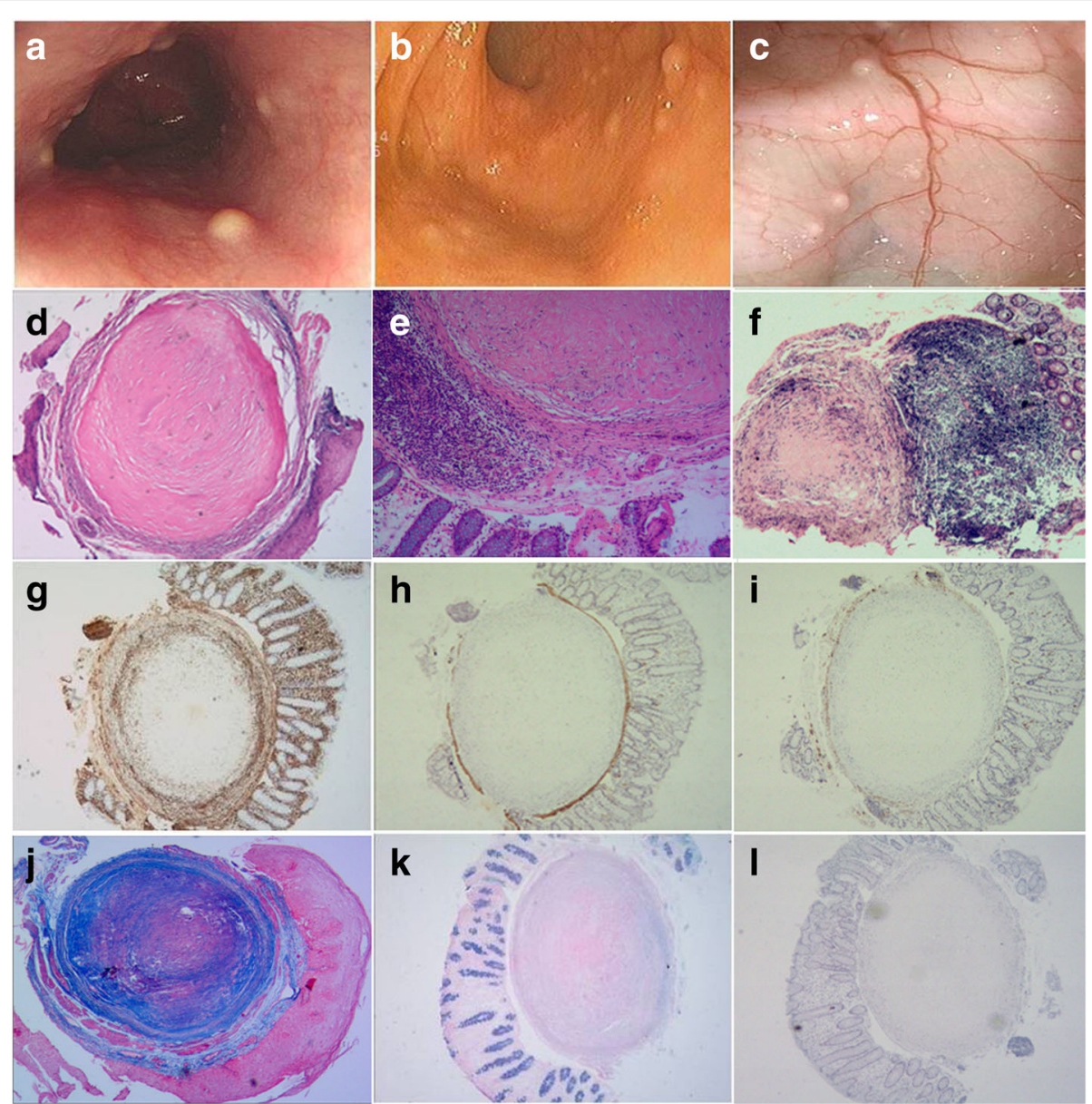

Fig. 1 Endoscopy revealed that hundreds of small nodules distributed in esophagus (a), terminal ileum (b), and colon (c). Histologically, several small round nodules located in the submucosa. Most nodules were composed of a large number of collagen and scarce stellate tumor cells (d: H\&E $\times 200$, e:H\&E $\times 400)$. In some nodules, tumor cells were abundant (f: H\&E $\times 200)$. The tumor cells showed positive for vim $(\mathbf{g})$, and negative for $h$-CALD (h, the smooth muscle of muscularis mucosae was positive), CD34 (i, the vascular endothelium was positive). The lesions were blue with Masson Trichrome stain (j, the smooth muscle of muscularis mucosae was stained red), red with PAS stain $(\mathbf{k})$, and pink with Congo red stain (I)

diffusely. In all of the lesions, inflammatory cells, calcification, mitoses and necrosis were absent.

Immunohistochemically, the neoplastic cells showed strong cytoplasmic vimentin staining (Fig. 1g), absent hCALD (Fig. 1h), CD34 (Fig. 1i), desmin, CD163, AE1/ AE3, CK7 and CK20 staining. The proliferation rate, measured by detection of ki-67 antigen expression, was very low (approximately positive in $1 \%$ tumor cells). Histochemically, the lesions were blue with Masson Trichrome stain (Fig. 1j), red with periodic acid Schiff (PAS) stain (Fig. 1k), and pink with Congo red stain (Fig. 11). Based on these features, the pathological diagnosis was eruptive collagenoma.

After diagnosis, the patient was given some medicines of proton pump inhibitors and modulating intestinal flora for her symptoms, and no specific treatment was given for collagenoma. One month later, all of the discomfort disappeared. After that, she had a routine endoscopy examination once in 6 months. As of September 2016, no obvious progress was observed.

\section{Discussion}

Collagenomas belong to connective tissue nevi (hamartomas), and are composed predominantly of collagen. They are divided into inherited and acquired. Inherited collagenomas are autosomal dominantly inherited, including familial cutaneous collagenoma and Shagreen patch of tuberous sclerosis. Acquired collagenomas include isolated collagenoma and eruptive collagenoma depending on the number of lesions [15].

Eruptive collagenoma, nevus anelasticus and papular elastorrhexis are closely related entities. Based on the similar clinical and histopathological features, some authors considered they represent a single disease spectrum $[3,16,17]$. They have common features in terms of peak age of onset, distribution of lesions, and a lack of history 
of trauma. Histologically, the lesion is composed of plump stellate tumor cells, sometimes with interspersed giant multinucleate cells. Romos et al. studied four cutaneous collagenomas using ultrastructural and immunohistochemical analysis. Their findings confirmed that the tumor cells were fibroblastic cells [18]. Collagen deposition was obvious in almost all of the tumors. Occasionally it was the main component of the tumor. In a research published in 2016, Seung et al. evaluated the status of collagen tissue in eruptive collagenoma, nevus anelasticus and papular elastorrhexis. The selected cases were reclassified into three groups: normal collagen group; fine, dense collagen group; and thick, dense collagen group [19]. This study indicated that different kinds of collagen could be observed in collagenomas probably in accordance with different stages of the tumor.

Clinically, all previous cases of eruptive collagenoma were represented with asymptomatic multiple cutaneous nodules. The nodules were skin-colored, dome shaped and usually less than $1 \mathrm{~cm}$ in diameter. They occurred mainly on the trunk and upper extremities [2]. The majority age of onset is the first two decades of life. However, there were some cases reported in the later years of life [4, $6,20]$. In our present case, the patient is an old female. Strangely, the lesions were distributed in the submucosa of whole esophagus and intestine. The features of immunohistochemistry were similar to those of eruptive collagenoma reported previously [18]. Masson Trichrome stain confirmed the masses were composed of fibroblastic cells and collagen. And there were no family history and associated disorders. All of these were in favor of the diagnosis of eruptive collagenoma.

The lesions should be differentiated from some other tumors which could be both multinodular and collagenous. Amyloidosis is the first tumor that should be differentiated. It is characterized by abnormal extracellular deposition of specific protein and protein derivatives, which are arranged in a $\beta$-pleated sheet structure. There are usually no tumor cells in the lesions. And Congo red stain is red but not pink. These features can distinguish it from eruptive collagenoma. It should also be differentiated from fibromas and plexiform fibromyxoma. Fibromas (fibrous histiocytomas) are ill-defined, characterized by a variable number of spindle and/or rounded cells. A variable admixture of inflammatory cells, coarse collagen bundles in haphazard array are present. Plexiform fibromyxoma (plexiform angiomyxoid myofibroblastic tumor) is a rare benign mesenchymal tumor. The plexiform growth of bland spindle cells in a richly vascularized fibromyxoid stroma is distinctive. GIST is another tumor that should be distinguished. It is the most common primary mesenchymal tumor of the gastrointestinal tract and has a broad morphological spectrum. The tumor cells are usually positive for CD117 and CD34.
So far, the pathogenesis of eruptive collagenoma was not clear. Uitto et al. commented that collagen accumulation is probably associated with a reduced collagenase [21]. Some other investigators considered that hormone may play a role in this disease $[5,22]$. Our patient is with a slightly abnormal level of IgG, IgA, complement C3 and complement $\mathrm{C} 4$. Whether it is associated with immune system disorder is worthy of further studying.

\section{Conclusion}

We describe a case of eruptive collagenoma occurring in the submucosa of esophagus and intestine, which have never been reported with eruptive collagenoma. We estimate that there are some changes of collagen in the submucosa of gastrointestinal tract that are similar to those on the skin.

\section{Abbreviation}

PAS: Periodic acid Schiff

\section{Acknowledgments}

Not applicable.

Funding

There is no any financial support for this work.

Availability of data and materials

Data sharing not applicable to this article as no datasets were generated or analyzed during the current study.

\section{Authors' contributions}

$\mathrm{HJ}$ and GP designed the study, performed the histological evaluation, and drafted the manuscript. JL participated in immunohistochemical evaluation. $\mathrm{HH}$ and ZC participated in literature search. All authors read and approved the final manuscript.

\section{Authors' information}

Not applicable.

\section{Competing interests}

The authors declare that they have no competing interests.

\section{Consent for publication}

Written informed consent for publication of their clinical details and clinical images was obtained from the patient. A copy of the consent form is available for review by the Editor of this journal.

Ethics approval and consent to participate

The study was performed in accordance with the Declaration of Helsinki, and it has obtained the approval from ethics committee of Yantai Affiliated Hospital of Binzhou Medical University.

Received: 23 September 2016 Accepted: 28 February 2017

Published online: 20 March 2017

\section{References}

1. Cramer HJ. On the clinical aspects of the so-called "eruptive collagenoma". Hautarzt. 1966:17:437-40.

2. Smith LR, Bernstein BD. Eruptive collagenoma. Arch Dermatol. 1978;114:1710-11.

3. Lee SH, Park SH, Song KY, Yoon TJ, Kim TH. Papular elastorrhexis in childhood improved by intralesional injections of triamcinolone. J Dermatol. 2001;28:569-71.

4. Betti R, Inselvini E, Pazzini C, Moneghini L, Crosti C. Symmetrical, papular, eruptive auricular collagenomas. J Am Acad Dermatol. 1998;39:363-4.

5. McClung AA, Blumberg MA, Huttenbach Y, Colome-Grimmer MI, Raimer SS. Development of collagenomas during pregnancy. J Am Acad Dermatol. 2005;53(Suppl):150-3. 
6. Amaya M, Okubo Y, Koga M. A case of eruptive collagenoma localized on the neck and shoulders. J Dermatol. 2002;29:79-85.

7. Yahya H, Rafindadi AH. Eruptive collagenoma in a Nigerian girl. Int J Dermatol. 2006:45:1344-6.

8. Xia Y, Darling TN. Darling, Rapidly growing collagenomas in multiple endocrine neoplasia type I. J Am Acad Dermatol. 2007;56:877-80.

9. Batra P, Loyd A, Patel R, Walters R, Stein JA. Eruptive collagenomas. Dermatol Online J. 2010;16:3.

10. Kang MH, Kim HJ, Seo YJ, Park EJ, Kim CW, Cho HJ, Kim KH, Kim KJ. A case of eruptive collagenoma on the left calf. Ann Dermatol. 2008;20:130-3.

11. de Almeida HL, Jr Breunig Jde A, Wolter M, de Castro LA, Rocha NM. Light and electron microscopy of eruptive collagenoma. J Cutan Pathol. 2009;36:35-8.

12. Zhao C, Ma W, Wang Y, Sun Q. Female with eruptive collagenoma clustered in the left lateral aspect of the abdomen. J Dermatol. 2010;37:843-5.

13. Kim HR, Na CH, Shin BS, Choi KC, Kim MS. A case of eruptive collagenoma. Korean J Dermatol. 2012;50:539-43.

14. Xiao M, Yang L, Dong L, Wang Y, Sun $X$, Tao J. Three cases of eruptive collagenoma and a literature review, 1970-2012. Eur J Dermatol. 2014;24:384-5.

15. Pierarad GE, Lapiere CM. Nevi of connective tissue. A reappraisal of their classification. Am J Dermatopathol. 1985;7:325-33.

16. Ryder HF, Antaya RJ. Nevus anelasticus, papular elastorrhexis, and eruptive collagenoma. clinically similar entities with focal absence of elastic fibers in childhood. Pediatr Dermatol. 2005;22:153-7.

17. Bordas X, Ferrandiz C, Ribera M, Galofre E. Papular elastorrhexis: a variety of nevus anelasticus? Arch Dermatol. 1987;123:433-4.

18. Ramos D, Monteagudo C, Carda C, Ramo'n D, Gonza'lez-Devesa M, Llombart-Bosch A. Ultrastructural and immunohistochemical characterization of the so-called giant multinucleate cells in cutaneous collagenomas. Histopathology. 2002;41:134-43.

19. Lee $\mathrm{SH}$, Sung NH. The importance of collagen tissue in papular elastorrhexis, eruptive collagenoma, and nevus anelasticus. Ann Dermatol. 2016;28:210-5.

20. Ju Q, Song N, Sun J. Eruptive cutaneous collagenoma in a Chinese patient. J Dermatol. 2011;38:399-401.

21. Uitto J, Bauer EA, Santa Cruz DJ, Holtmann B, Eisen AZ. Decreased collagenase production by regional fibroblasts cultured from skin of a patient with connective tissue nevi of the collagen type. J Invest Dermatol. 1982;78:136-40.

22. Uitto J, Santa Cruz DJ, Eisen AZ. Connective tissue nevi of the skin. Clinical, genetic, and histopathologic classification of hamartomas of the collagen, elastin, and proteoglycan type. J Am Acad Dermatol. 1980:3:441-61.

\section{Submit your next manuscript to BioMed Central and we will help you at every step:}

- We accept pre-submission inquiries

- Our selector tool helps you to find the most relevant journal

- We provide round the clock customer support

- Convenient online submission

- Thorough peer review

- Inclusion in PubMed and all major indexing services

- Maximum visibility for your research

Submit your manuscript at wuw biomedcentral.com/submit

C Biomed Central 